\title{
Coagulopathy associated with COVID-19
}

\author{
Stephanie G. Lee MD MSc, Michael Fralick MD PhD, Michelle Sholzberg MDCM MSc
}

Cite as: CMAJ 2020 May 25;192:E583. doi: 10.1503/cmaj.200685; early-released May 1, 2020

1

About $20 \%-55 \%$ of patients admitted to hospital for coronavirus disease 2019 (COVID-19) have laboratory evidence of coagulopathy Coagulopathy correlates with severity of COVID-19 and may include increased $\mathrm{D}$-dimer concentrations ( $\geq 2$ times above normal range), mildly prolonged prothrombin time ( 1-3 s prolongation above normal range), mild thrombocytopenia (platelet count $>100 \times 10^{9} / \mathrm{L}$ ) and, in late disease, decreased fibrinogen levels $(<2 \mathrm{~g} / \mathrm{L}[5.88 \mu \mathrm{mol} / \mathrm{L}]) .^{1-3}$ It is uncertain whether the observed coagulopathy is caused directly by the virus or is secondary to a proinflammatory state.

2

Elevated D-dimer concentration is associated with poor clinical outcomes

It is unclear how a D-dimer result should specifically be used in clinical care. However, an increased concentration at the time of hospital admission and throughout the hospital stay is associated with death, $, 1,2$ and a concentration 4 times above normal is associated with an approximately fivefold higher odds of critical illness than a normal D-dimer concentration (www.medrxiv.org/content/10.1101/2020.04.08.20057794v1.full.pdf).

COVID-19-associated coagulopathy appears to be prothrombotic

In 2 retrospective studies, venous thromboembolism was diagnosed in about 1 in 4 patients admitted to the intensive care unit with COVID-19.,5 In 1 study, this occurred despite thromboprophylaxis with low-molecularweight heparin. ${ }^{5}$ Available studies have not reported bleeding as a common complication, although the literature is evolving rapidly. ${ }^{2,4,5}$

4.

In the absence of a contraindication, patients admitted to hospital should receive venous thromboembolism prophylaxis as per standard of care

Venous thromboembolism prophylaxis is recommended for most admitted patients, especially those with a proinflammatory state. In 1 retrospective study, patients with a D-dimer concentration 6 times above normal who received heparin thromboprophylaxis (mostly enoxaparin $40-60 \mathrm{mg} / \mathrm{d}$ ) had lower mortality than those who did not receive thromboprophylaxis. ${ }^{6}$

\section{Transfusion of blood products should be avoided in patients} who do not have active, major bleeding

Transfusing with the aim of correcting only hemostatic laboratory parameters can be harmful (e.g., risk of transfusion reaction), regardless of whether the patient has COVID-19. Patients with active, major bleeding should be transfused appropriately as per local protocol.

\section{References}

1. Tang N, Li D, Wang X, et al. Abnormal coagulation parameters are associated with poor prognosis in patients with novel coronavirus pneumonia. J Thromb Haemost 2020;18: 844-7.

2. Zhou F, Yu T, Du R, et al. Clinical course and risk factors for mortality of adult inpatients with COVID-19 in Wuhan, China: a retrospective cohort study. Lancet 2020;395:1054-62.

3. Richardson S, Hirsch JS, Narasimhan M, et al. Presenting characteristics, comorbidities, and outcomes among 5700 patients hospitalized with COVID-19 in the New York City area. JAMA 2020 Apr. 22 [Epub ahead of print]. doi: 10.1001/ jama.2020.6775.

4. Cui S, Chen S, Li X, et al. Prevalence of venous thromboembolism in patients with severe novel coronavirus pneumonia. J Thromb Haemost 2020 Apr. 9 [Epub ahead of print]. doi: 10.1111/jth.14830.

5. Klok FA, Kruip MJHA, van der Meer NJM, et al. Incidence of thrombotic complications in critically ill ICU patients with COVID-19. Thromb Res 2020 Apr 10 [Epub ahead of print]. pii: S0049-3848(20)30120-1. doi: 10.1016/j.thromres.2020.04.013.

6. Tang N, Bai H, Chen X, et al. Anticoagulant treatment is associated with decreased mortality in severe coronavirus disease 2019 patients with coagulopathy. J Thromb Haemost 2020 Mar. 27 [Epub ahead of print]. doi: 10.1111/jth.14817.

Competing interests: Michael Fralick is a co-investigator and Michelle Sholzberg is a principal investigator on a clinical trial involving patients with COVID-19 coagulopathy. No other competing interests were declared.

This article has been peer reviewed.

Affiliations: St. Michael's Hospital (Lee) and Department of Medicine, University of Toronto; Sinai Health System and Department of Medicine (Fralick), University of Toronto; St. Michael's Hospital and Departments of Medicine, and Laboratory Medicine and Pathobiology (Sholzberg), Li Ka Shing Knowledge Institute, University of Toronto, Toronto, Ont.

Correspondence to: Michelle Sholzberg, Michelle. Sholzberg@unityhealth.to

CMAJ invites submissions to "Five things to know about ..." Submit manuscripts online at http://mc. manuscriptcentral.com/cmaj 